\title{
Corporate Social Responsibility and Corporate Financial Performance: Case Study of Pakistan
}

\author{
Mahmoud Y. M. Kaskeen \\ International Islamic University Islamabad, Pakistan
}

Copyright $\odot 2017$ by authors, all rights reserved. Authors agree that this article remains permanently open access under the terms of the Creative Commons Attribution License 4.0 International License

\begin{abstract}
Purpose: The relationship between corporate social responsibility (CSR) and corporate financial performance has been subject to extensive empirical enquiry. Yet the body of evidence that has accumulated about the nature of the relationship is equivocal. Purpose of this research is to explore the impact of Corporate Social Responsibility (CSR) on Firm Performance while controlling the impact of Firm Specific variables for Pakistani Manufacturing Sector. Methodology: We measure CSR by taking three sub variables, whereas $\mathrm{CP}$ measurement approaches include accounting-based measures, market-based measures and combined measures. We used panel least square method by using fixed effect model, we took 56 cross sections (Companies listed on KSE) with six years of time series, and thus we gathered or estimated on 336 firm year observational data. Results: we performed Housman and test statistics favored for fixed effect model for equations. Multiple regression results reveals that Donations has strong negative effects on accounting based market returns, while coefficient is not statistically significant from zero for Earning per share, while workers profit participation fund and Workers welfare funds has strong significant impact on financial performance in term of accounting, equity and market base. However Earning before earning and tax and firm growth (our control variables) coefficients has shown strong positive impact on financial performance, while firm cash availability has negative impact on financial performance for sample under study. After control long firm specific variables we found a strong significant impact of CSR on FP for Pakistani manufacturing sector. Practical Implications: The results of said research would help corporate executives and financial managers for execution of owners' wealth goal (Financial Profitability) by implementing proper CSR practices in manufacturing sector companies.
\end{abstract}

Keywords Corporate Financial Profitability, CSR, Financial Performance, ROA, ROE, EPS, WWPF, WPF

\section{Introduction}

It is a well-known fact that businesses are currently incorporating corporate social responsibility (henceforth, CSR) criteria into their activities. The demands of a changing environment have led firms to pay ever greater attention to their influence over it, both in economic and social terms and those of the environment. The term corporate social responsibility possibly has been expanded from most recent decades. A large number of companies are genuinely engaged with corporate social responsibility exercises and demonstrate all parts of CSR and their impact on financial related benefit of the business. CSR examines economic, lawful, ethics, social and physical parts of environment. Corporate Social Responsibility (CSR) is a procedure having the motive to grasp the corporate's obligations through its activities and positive inspiration, workers, society contribution, corporate responsibility, shareholders and all individuals from public sphere, and how to maintain their stakeholders.

Due to the firm's goodwill and reputation CSR awareness and its importance is growing (Kang, Lee et al. 2010). CSR has inclined to become an essential element of manufacturing sector in Pakistan in recent years. Manufacturing sector is the business who involved in expected returns. Its fact, greater the level of profitability of companies consequently lead them to spare more amount for social work. In short, amount of profitability ultimately relates to the CSR performance. Presently paractice of Corporate Social Responsibility (CSR) is not viewed as a cost, it is filling in as an investment (Wibisono 2007). These performances cannot be accelerate without generating a reasonable money. It narrates companies which attempted to avhieve high levels of CSR in consequence attain accomplishment in the market and it is considered a key success for industries under taking CSR 
paractices. At the same time, this generated amount of profit can only be utilizes to address the social accountabilities. Surplus firms promote positive image and feels proud in the eyes of the society by highlitening and accomplishing their performance. CSR implies that a company ought to be considered responsible for any of its activities that influence individuals, groups and nature in which those individuals or groups live (Mitnick 1995). (Carroll 1979) proposes that CSR is characterized as the financial, legitimate and moral requests that community places on business. (Angelidis and Ibrahim 1993) characterized CSR as "corporate social activities whose reason for existing is to fulfill social needs".

Social Responsibilities describes that corporate behavior must not simply ensure return to shareholders, compensations to representatives and things and organizations to buyers, then again they ought to respond to societal and characteristic concerns and regard (Solihin and Citra 2009). In fact, (Baron 2001) arguing that "Corporate social obligation is an evil and not entirely characterized idea." We rely on upon the wide definition proposed by the World Business Council for Sustainable Development (WBCSD 2004), which contended that "CSR is the assurance of a dare to add to economical economy improvement, working with workers and representatives, their families, the neighborhood society gathering and group all over the place to upgrade their personal life.

It is furthur, supposed that corporate social responsibility has positive strong relation with corporate's financial performance. Likewise, it is true for the chosen sector. It is dissected that the manufacturing sub-sectors which direct CSR exercises, at last upgrade their financial position and help up productivity by winning a name in the public eye through its positive picture. Similarly, this sector is well-known and considered more liable among public. At same time CSR exercises in organizations are on deliberate premise. In 2002, survey Price Water House Cooper's International concluded that CSR is an integral requirement for companies survival and growth, above the $70 \%$ of the international executive are considered this fact. At the same time, it is strongly believed that organizations cannot exist or prosper isolate in the society where it operates, without doing well-being giving something back to the society. An enlarging desire for clarity increasing desires as far as firms' financial measures and how they enhancing their society interminably, ecological and financial related presentation. This very interestingly contribute from (Turker 2009) offered the perception of stakeholders, customers, employees and government to analysis the relation of CSR to firm's commitment.

The implementation of CSR is contrast in each industry, such as organizations' size, the business nature; desires resulted by shareholders, and how continuously these commercial ventures are participate in CSR. A few sub-segments focus on a particular area regarded to the most notable for them or where they demonstrate over the top impact instruction, for instance or the social as for others they expect to center the all aspects of them. CSR always was mainly concerned with the strategies having people as their focal point. In history (Bowen and Johnson 1953) thought the social obligations of business at that age, the responsibilities of businessmen to follow those regulates to take actions and follow those action lines, which are the main objectives and value worthy of the society in terms of desire. He focused on making the decision by the management and commitments to the higher society, not just those centers to business. This leading state can be compared with CSR, which in present day emphasize to the larger institutional and corporate practices rather than individual manager decision making. The companies' CSR work on beginning stage ought to be CSR technique, as it characterized; inner perspective: before characterizing what you need to accomplish with this system you require strong support for the methodology. Outside viewpoint: it will go about as the situating report for the capable business you practice of your business.

Currently, manufacturing sector is more cautious and concerned about the importance of CSR practices and social responsibilities. Manufacturing sector is under more pressure than other organizations to prove their glass regarding to CSR. Organizations themselves are additionally finding a way to uncover their CSR activities to different shareholders. It is not the volume of revelation that matters, but rather the variety of things unveiled and fixation to the authoritative partners.

Socially responsible firms come into contact with many societal issues like human rights, environmental sustainability, community investing cost, competition problems and stakeholder issues, these strong societal problems can be well addressed by freely elected governments. As firms' poor resources are not suited for addressing their societal affairs, and hence, it is argued, they should not be misplaced. Definitely, its cost involving acquires the CSR principles. These occurring costs could be for short or continued outflows in nature. These firms might suffer the charge involving the purchase of new management structure and environment equipment etc. Being implicating these social costs, it should produce a pay-back in order to a defendable entity execution. In addition, socially responsible companies are rarely confronted with negative events, damaging reputation and spending millions in advertising information movement.

Companies that carry CSR actively, their products and services are higher worthy and more trusted. Still many corporations have been criticized for irresponsible operations such as, injustice treatment with stakeholders, pollution, environmental mortification; profit is sole motive, ethical issues and so on. In this scenario how firms could be known socially responsible and get a good repute where they operate. The implementation of CSR practices in developing countries is limited or ignored. It may be due to the lack of awareness or poor communication etc. To put 
it plainly, the length of it concerned CSR has need awareness in Pakistani societies, organizations and overall population are less alert in availing their rights and obligations. As contrast with CSR acknowledgment in associations and open is prone to be less in Pakistan and conversely developed world is many ways ahead. Also the nation is ceaselessly striking the inconveniences vitality emergencies, natural debacle, terrorism, increasing rate of inflation, social indecencies, absence of framework identified with wellbeing and training, poor law and rules circumstances bubbling economy kept down investment. Corporate social obligation is dominatingly reflected wonder of western, wonder because of solid organizations, measures, and claim frameworks founding weak progressing nations of Asia (Chapple and Moon 2005). Asian's developing including Pakistan these weak measures posture significant test to firms for engaging CSR.

The study investigates the CSR practices and impact of its elements especially with respect to manufacturing sector of Pakistan. The purpose of present study is to overcome the gap and build up the conceptualization of CSR to investigate the prevailing issues and link between Manufacturing Sector's monetary and social execution concern. The sorted out parts of this research are as per the following; first section contains on presentation of related subject. In second section literature background and hypothesis are developed. In section third model and methodology specification is determined. Section fourth describes analysis, results and discussion. Lastly, summary of conclusion and recommendations are talked about.

\section{Three Approaches to Corporate Responsibility}

As traditional perspective of the organization, it exists fundamentally to make benefits. From this money-focused point of view, seeing that business morals are essential, when organizations are imagined as holding an extensive range of economic and community obligations as a major part of their everyday operation, the field of business morals extends correspondingly. Presently there are huge sets of issues that should be managed and confronted outside of, and independently struggle for the money. Extensively, following three theoretical approaches with deal to these new responsibilities:

\section{Corporate Social Responsibility (CSR)}

The corporate social responsibility title has two meanings. First, corporation underlines both to make profit and the responsibility and the obligation to cooperate moral obligation with the surrounding environment. Secondly, corporate social responsibility is likewise a specific conception that commit to advantage while expecting a section in more broad inquiry of community welfare.

A particular theory company's way to connect with the world society and larger world, CSR is composed of these four obligations:

- The economic sustainability, demanded by simple matters of economy commitment of the business adjustment of the human survival instinct. Association does not make advantages are - in a present day market economy-bound to die. Non-production cash partnerships profit (from their own specific activities furthermore through donations), In like manner, private and non-private can work without turning an advantage. In a couple of urban societies, waste picking corporation is dealt with by this kind of affiliation, one that keeps the streets clean without making anyone rich. For most by a wide margin of operations, regardless, there must be advantages. Without them, it arrives no business furthermore not business morals.

- The legal sustainability, to adhere to principles. In past, this responsibility is not controversial base. What promoters of CSR battle, regardless, are that this dedication must be fathomed as a proactive commitment? That is, laws aren't restricts that ventures skirt and navigate if the required punishment is low; rather, mindful affiliations recognize the strategy as a social best and make extraordinary confidence to comply with the letter and in addition the points of confinement of the soul. In strong terms, this is the qualification between the driver who stays under beyond what many would consider possible in light of the fact that he can't hold up under the expense of a development ticket, and one who obeys in light of the way that society by and large is served when we all agree to respect the signs and stoplights and purposes of confinement.

- The ethical sustainability, to make the wisest decision notwithstanding which not required by the spirit of law. Corporate society that points of view the business itself as an occupant in general society eye, with the kind of duties that citizenship ordinarily includes. From a perspective that values everyone's welfare as being gainful, the measure could be recommendable.

- The philanthropic sustainability, contribution towards the society's exercises notwithstanding when they're free of the particular business. It rises as duties extending from the regular operations of the business included. They're not enjoying the commitment a compound firm has for safe exchange of its waste. Maybe, these uncover exhibits of magnanimity address a point of view that associations, as everyone in this world, have some contribution to bolster the general public welfare in the routes directed by the needs of the surrounding society. 


\section{The Triple Bottom Line}

The triple bottom line is a type of corporate social action managing that corporate pioneers organize primary concern results in economic terms (costs versus income) as well as far as organization impacts in the social domain, and environment as a regard. There are two keys to this thought. Firstly, the three sections of obligation must be kept apart, with independent results reported for each. Secondly, in every one of the three of these parts, the organization ought to acquire sustainable results. The idea of sustainability is particular. At the crossing point of morals and economics aspects, sustainability implies the balance of maintenance for long term. As explained by scholars including John Elkington, here's the way the equalization is defined and accomplished economically, socially, and environmentally:

\section{Economic Sustainability}

Long term financial solidity values more unstable, short term benefits, how high does not matter. According the triple-bottom line model, large companies have an obligation to make strategies permitting prolonged and stable activity. It's actual that weighting the business plans may prompt fortunes, means esteeming marketable strategies that may not prompt speedy wealth but rather that likewise keep away from calamitous losses. This probability leads quickly to the result that sympathy toward corporate sustainability in financial related terms contends against the dumping.

\section{Social Sustainability}

Values in individuals' lives and the way we live. A world in which a couple Fortune 500 executives are pulling down millions a year, other millions of individuals somewhere else in this world living on pennies per day can't go on until the end of time. As the irregular growth, as the wealthy get wealthier and the poor get poorer and more various, chances by society itself will fall in outrage and insurgency increment. The danger of administrative topples from underneath sounds remote-verging on foolish. For a business to be steady over the long haul, opportunities and along these lines riches should be spread out to cover however many individuals as could be expected under the circumstance.

\section{Environmental Sustainability}

Starts from the affirmation that natural resources particularly the oil fueling our motors, the perfect air us inhale, and the water we drink are restricted. On the off chance that those things decay significantly, our kids won't have the chance to enjoy the same quality of satisfaction the greater part of us experience. Protection of resources, accordingly, therefore vital, as does the improvement of energy's' new sources that may substitute those we're as of now using.

\section{Stakeholder Theory}

This theory has been defined by Edward Freeman 1984 and others, is the mirror picture of corporate social responsibility. Rather than beginning with a business and watching out into the world to see what moral commitments arrive, in the world stakeholder theory begins on. It records and depicts those groups and individuals who will be influenced by (or influence) the organization's activities and asks, "What are their law cases on the business?" "What rights do they have concerning the organization's activities?" and "What sort of obligations and commitments would they be able to legitimately force on a specific business?" stakeholders theory confirms that who lives and touched by an enterprise hold an obligation and right to take participate in its directing.

\section{Why Map CSR in Pakistan}

CSR is currently a mainstream business administration issue the world over. A developing body of research is advancing the business case for environmentally and socially responsive corporate part. This was not generally so. The nineties are accepted to be a watershed while pushing CSR towards the highest point of the agenda taking after a groundswell of purchaser concern about models of corporate conduct along item supply chains crossing the globe.

With product integrity issues going up against brands like Nike and Martha Stewart, to process uprightness issues highlighted amid the Shell and Barings scenes, the moral measurements of an undertaking's behavior turned into a center of open debate not just inside of citizen part associations where it had begun, yet among top leaders in Government. Securities and Exchange Commission of Pakistan (SECP) has made a first commitment with its Code of Corporate Governance, and the 2002 Exchange Policy explained surprisingly the administration's plan to mainstream multinational industry benchmarks through suitable institutional support.

Pakistan itself has needed to learn rapidly in adjusting to the CSR worldview. The nation's carpet industry endured loss around a billion dollars through the 1990s as a consequence of the Iqbal Masih case, while the sporting products industry stepped far from the edge strictly when the Sialkot Partnership drove by industry affiliations united the government, ILO and citizen division associations to battle child work. From that point forward the country's edible products and textile export industries have kept on confronting demands by international purchasers for CSR credentials.

Inside of this environment, it is unavoidable for Pakistan to effectively consider proof based strategy improvement as an initial move towards making an all-around coordinated and significant CSR in Pakistani culture. We have various cases of corporate philanthropy, which are consistently displayed as CSR. To investigate how 
profoundly corporate qualities are embedded in associations and to look at the role values are playing in Pakistan's culture.

\section{Principles of CSR}

Due to the instability encompassing the way of CSR action it is hard to assess any such activity. It is along these to have the capacity to recognize such contend actions and there are three fundamental principles which together include all CSR activities. These are:

- Sustainability;

- Accountability;

- Transparency;

\section{CSR Practices in Pakistan}

Condition of CSR in Pakistan is still in its early stages. Just few organizations have a current CSR strategy and generally they are the multinationals who take after their own particular CSR standards and strategies. Unluckily, the local business is either unconscious of the advantages brought by CSR or they feel that regardless of the fact that they don't adopt such strategies, they are not in any condition of danger. The lack of the local concern part was highlighted in the 1996 by the breakdown of the carpet local industry and the danger of harm to Sialkot's games industry. Exploitation of labor, child work, deficient employee's advantages and unacceptable workplace were couple of zones pinpointed by the global eye. Despite the fact that taking the prompt measures, the combined effort of the industrialists spared the more noteworthy harm foreseen, yet very little has been done to take more active measures.

In 2003 a discussion of multi stakeholders "Pakistan Compliance activity" was dispatched with support from global buyers, the textile area, what's more, the Ministry of Commerce. A draft national standard was produced for use as consistence standard endorsed by Government to replace numerous Universal social and environment. Compliance measures and purchasers imply rules. The aftereffect of this effort was incorporation of social compliance in the exchange policy and start of a business proposition by Ministry of Science moreover, Technology to European Union for subsidizing so as to empower SA800 usage counseling and implementation cost.

In context of Pakistan CSR is habitually likened with corporate generosity, the terms being frequently erroneously used synonymously. Some thought CSR to be a straightforward compliance with law. This makes a trouble on the grounds that top administration is still uncertain about the fair implications of CSR. This demonstrates the requirement for a mass mindfulness campaign upheld by the government, focusing on representatives, entrepreneurs and clients with the goal that they can acknowledge CSR furthermore the general dangers of rebelliousness in today's surroundings.
Successive and open dialog understanding and defining CSR, itemizing its nature and advancing and creating philosophies on how local organizations embrace and deal with their CSR commitments would be a valuable initial step.

\section{Objectives of the Study}

1. The main objective of the current study is to explore exclusively and potentially the practices carried out by manufacturing sector related to Corporate Social Responsibility (CSR) activities.

2. To find out whether CSR practices are influencing positively or negatively the financial position of these sub-sectors in the Pakistan.

3. Lastly, to check out the relationship in CSR and Corporate Financial Performance in manufacturing sector of the Pakistan.

\section{Study Significance}

Manufacturing sector is mainly participating in the economy of Pakistan. It has importance for exporting the finished goods. This research has main value to provide how much social responsibilities are important for this sector. Researcher has successfully accomplished this project to suggest if companies in these sectors follow CSR do really yield advantages. It provides the complete understanding of relationship between corporate social responsibilities and financial performance for manufacturing sector of Pakistan.

\section{Review of the Literature}

Since 1950s the CSR concept was familiarized, regarding its stimulus effect on enhancing firms value, the definitions, debates and many studies remained matter of considerable under the scholars inquiry. Therefore, it is interested to understand CSR factor has a contribution to firm's financial performance, it is also provide insight that practices of CSR are influencing financial performance of firm's subsequent year (Yusoff, Mohamad et al. 2013). A few past exploration show there is certain relationship in the middle of's CSR and firm financial implementation.(Jo and Harjoto 2011) find there's emphatically optimistic conclusion for businesses that take part in CSR on firm regard. CSR furthermore have constructive and huge link by industry money associated execution (Cheung, Tan et al. 2010) and (Choi, Kwak et al. 2010). Differentiation find by (Nelling and Webb 2009) and (Mulyadi and Anwar 2011). Nelling and Webb inspect causal connection in the middle of CSR and monetary execution. (Lindgreen, Swaen et al. 2009) likewise have matching results. They presume that through contacting its partners through CSR, enterprise could make their earnings and welfares, which therefore boosts their explosion of receiving by over the extended 
time. Researchers came across a positive, a negative, a curvilinear and even a zero relationship between CSR and CFP in previous studies (Barnett and Salomon 2006) and (Sen and Bhattacharya 2001). Organizations may respond to firm-particular official implementing via actualizing extra CSR activities, which thus might prompt to number of standards of CSR cross over industries (Bansal 2005),(Delmas and Toffel 2004),(Hoffman 2001) and (Kassinis and Vafeas 2006). Regarding the same case of relationship both (Lee and Park 2009) and (Kang, Lee et al . 2010) also remained failed to find the weighty effect of CSR on a firms financial position. It seems to be no clear liaison concerning corporate social responsibility acts and corporate financial performance. Better CSR of an organization investment decision of institutional financial specialists by enhancing an association's entrance to investment (Graves and Waddock 1994), (Pava and Krausz 1996) and diminishing the charge of investment. Studies builds up an ideal connection between society activities of companies and enhanced stable financial presentation (Brugmann and Prahalad 2007) and (Rockefeller 2003). As indicated by (Zairi and Peters 2002) an association's ability that produces sustainable wealth after some period and its lengthy haul quality are dictated through the association with together inner and outer partners. CSR, on the off chance that it adds to improving firm value. Several scholars have paid great attention to find continuous consistent results. Further, other two activities of CSR are parsing operation related (OR) and non-operation related (Non-OR) could not find significant relative on firm financial performance regardless of CSR different dimensions (Lee, Singal et al. 2013) . In addition, CSR dimensions may differentially use (Kang, Lee et al. 2010) and even accumulated negative as well as positive of these CSR activities. Moreover, disregarding CSR dimensions with associated conditions and using the same company lead to vary results (Campbell 2007) . Despite of inconsistent empirical results, numerous studies have originate that CSR activities positively impact CFP (Bird, Hall et al. 2007), (Orlitzky, Schmidt et al. 2003) and (Bragdon Jr and Marlin 1972). (Khanifar, Nazari et al. 2012) findings recommended blended results crosswise over diverse commercial enterprises and add to organizations' proper vital choice providing so as to make for CSR exercises more exact data with respect to the effects of each directional CSR movement on money related execution.

\section{CSR Indicators}

Different definitions and explanations of corporate social responsible activities entailed some benefits to the society beyond the self-centered, monetary motives of the firm and afar the severe requirements of the law (Kang, Lee et al. 2010). Following quite a while of broad research, no consensus has been come to so far in respect to why firms enlist in CSR activities. A few theories have been put ahead and they have been checked on recently by (Bénabou and Tirole 2010) and (Kitzmueller and Shimshack 2012). As contended by (Chapple and Moon 2005), Term CSR is considered an umbrella covering by synonymous and with different ideas of corporate community relatives. The prior research on CSR practices is broad, covering extensive range of sectors and all other aspects. So it's very difficult to determine the link of social and financial performances due to the complications and consensus lack of methodological measurement. CSR prompts numerous elusive advantages for the organization, for example, corporate image and reputation (Schwaiger 2004), better worker inspiration (Epstein and Roy 2001), enhanced trademark picture (Heal 2005). Despite the fact that past proposes a damaging connection amid CSR concerning the group and organization execution (Berman, Wicks et al. 1999) it is moreover perceived that interests in society improvement exercises assist a firm with obtaining aggressive returns over tax reserve funds, diminished administrative weight and changes in the nature of native worker (Waddock and Graves 1997). CSR is considered as evidence regarding to ethical quality (McWilliams and Siegel 2001). Association of commercial through the society is realized increase in education, wellbeing, and pay era. CSR towards to the group is perceived in terms of generous giving, non-public, public organizations, public connections, and interest in community and financial improvement issue. According to (Roberts 1992) and (Adams, Hill et al. 1998) it as that corporate bodies are eager and get motivated to implement the practices of CSR programs. We contend that customers are less inclined to react to CSR exercises, regardless of the fact that they know about them, if the CSR exercises are not affiliated to the association's repute for being a capable resident see likewise (Du, Bhattacharya et al. 2010) also (Schuler and Cording 2006). Then (Jensen 2001) concluded that corporate social responsibility is an organization's financial burden and negative effect on its performance also demonstrates that in definite conditions CSR improves the worth of the organization nonetheless it may in others, it could demolish quality, telling that a few organizations hold fast to the stakeholder model, and others may reflect more extensive objective. Moreover, (Roberts 1992), (Trotman and Bradley 1981) and (Mahapatra 1984) reasoned that social obligation exercises could prompt expanded deliberate hazard. In accordance to (Zahra and Stanton 1988) the companies are not reluctant to concerned more about social action and responsibilities. According to previous study (Trotman and Bradley 1981) small firms due to small scale of operations, less scale visibility, less interest in CSR initiatives. An absence of provable connection in the middle of CSR and firm actions regularly discouraging organizations from taking part in CSR (British Council 2002). Obstructions to CSR are observed 
to be specially appointed methodology by the top administration concerning CSR, absence of agreement on needs inside of the firm, and issues identified with estimation and assessment of CSR exercises (Krishna 1992). Uncertain strategies, system of government, poor checking, convoluted expense frameworks, also poor foundation region couple of additionally preventing components (Brown 2001). A developing number of researchers take the perspective that organizations can never again be seen absolutely as private foundations yet as social organizations rather (Moir 2001) and (Balabanis, Phillips et al. 1998). As indicated by (Ullmann 1985) and (Roberts 1992), if corporate social obligation is seen as a huge expense, organization with generally high previous monetary execution might be extra eager to assimilate these expenses later on. It is additionally estimated that poor entertainers would look for more prompt outcomes and thus they could favor transient and high return ventures to the unverifiable and when all is said in done longer-term CSR speculations. (Freeman 1984) work is considered as an establishment in characterizing the positive relationship in the middle of CSR and FP. He contended in the point of view of partner hypothesis that obligation of the association's administration now goes past the gainfulness and they must consider the get-togethers in their choices on the grounds that association's obligation is to fulfill the shareholders as well as to consider and fulfill a wide range of association's partners. Specifically, we depend on (Barnett 2007) understanding that the effect of CSR on corporation worth on upon the capability of CSR to impact participants in the firm. On the other hand, large scale firms take on more participations and have a distinguish impact on the society. With line in literature on business sustainability and the resource with perspective of the firm, organizations may take part in CSR with a specific end goal to enhance their proficiency and upgrade, e.g., their product image, reputation and confidence e.g. (Barney 1991),(Hart 1995) (Porter 1991),(Porter and Kramer 2006) also (Russo and Fouts 1997). Past studies have confirmed that firms which are socially responsible clearly display the inclination for providing the high quantity of CSR (Aras, Aybars et al. 2010), (Janggu, Joseph et al. 2007) and (Naser, Al-Khatib et al. 2002). Accordingly, society has a certain social agreement by the firm. In this manner, consequently for the exact to endeavor assets in the creation procedure, community has a case on the organization and the privilege to governor it. The particulars of this agreement can variate as social circumstances change yet this agreement by and large dependably leftovers the premise of the authenticity of the interest for or statement of the requirement for CSR (Epstein 1987). The main concern of the firm should related to minimize CSR, because they might be costly loosing the reputation, law claims and panalities (Singal 2014). From a business point of view, however a few scholars argued that CSR can enhance the cometitiveness of an organization (Burke and Logsdon 1996) and (Knox and Maklan 2004). It was defined (Ehsan and Kaleem 2012) that pakistani firms are participating in society's welfare in form of providing education, health care facilities, sustaining environment from harmful changes, moreover, they are more concious for their stakeholders to take them in trust and confidence, they working for workers welfare better living standards, in result, these expenditures not only bring social development but also achieve long term financial benefits. (Chatterji and Levine 2008) and (Chatterji, Levine et al. 2009) argue that the firms which are socially responsible, the firms evaluation and social enactment of enterprises can not truly distinguish, oftenly resulting in metrics that can be void and misleading. Major conflicting and complex reseaons for these positive, negative, no or neutral correlation in CSR and corporate financial presentation are lack of methodological and literature background. According to previous class of researchers who found no or neuteral conclusion, we cannot find it without mentioning (Lenssen, van den Berghe et al. 2005). (Arlow and Gannon 1982), in the wake of looking into seven studies bases on empirical, inferred that financial performance is not straightforwardly related, in each a positive or a negative path, to social awareness. This (Mason and Simmons 2011) article indicates how the conceptualization of CSR hard to moral reseaoning allows a firm's general CSR stand to be positioned on a social responsibility continum. An organization's advanced levels of CSR participate to larger financial performance and enrich the firm's human resources and functions of marketing. (Verwijmeren and Derwall 2010) and (Bae, Kang et al. 2011) both found that CSR organizations with a great reputation of worker prosperity shows lower leverage. This is on the grounds that lower leverage infers lower likelihood of default, One downside of the above observational studies is that they neglected to recognize past, simultaneous and resulting to CSR monetary execution, and in this manner to make conceivable solid deductions about bearing of causation. In a large portion of the past studies, financial execution secured a (normally five year) era "encompassing" the CSR execution and/or social exposure periods.

\section{Donation}

It is directed under Company Ordinance 1984, in compliance with part-III, E-I of schedule 4; SECP made it compulsory for all listed firms to highlight their social spending donation information in their profit and loss accounts. Companies must donate from their profitability for society prosperity. The voluntary amount is given by a firm for multiple purposes for the society benefit in terms of education, health care facilities and environment issues etc. This amount is deducted as a contribution towards society before calculating income tax. (Lin, Yang et al. 2009) existing and previous literature on financial 
performance and corporate social performance relationship depicts that there are number of studies who used this CSR dimension as a proxy such as (Seifert, Morris et al. 2004). In context of Pakistan probably all companies uncover their social actions report concerns to the donations as a head which contains (Makki and Lodhi 2008) like charity, education, health facilities, aid, environment sustainability projects and community betterment programs. (Muller and Kolk 2010) and all previous mentioned studies measured this CSR dimension. With a specific goal to satisfy the part of CSR and to improve charity participation should develop non-benefit framework to accomplish their goals extra cost-adequately. On the other side, the Islamic aids can likewise get advantages with commercial structure usage of the corporate associations and to make commitments all the more successfully in the society division (Hassan and Salma Binti Abdul Latiff 2009). Interestingly, after an Islamic viewpoint, CSR practiced in business association or is perceived as an advantage as opposed to an expense. Islamic trade morals has given diverse measurement and a vital strategy to consider charity works (Abu-Sulayman 1976). (Zairi and Peters 2002) proposed a specific rate of corporate profit to society involvement as donations that can be utilized to target and concentrate on charitable work, supporting wellbeing, education and welfare. Companies must spend money as per the terms of the reliance, it is most vital of which is satisfying the necessities of poor people (Naqvi 1981). It might be clear which altruistic associations increase the cash, have the best honor or deal with the improved campaigns. (Friedman 2007) further states that if charitable commitments are completed, it ought to be made on separate stockholders basis or by expansion, singular representatives but not by the company. The earlier literature, with the essence of participants theory e.g. (Friedman 1962) sees social obligation as a "donation" from shareholders to towards stakeholders that decreases profits. So also, CSR may be the result of an agency confrontation in the middle of shareholders and directors (Jensen and Meckling 1976): organizations' social engagement may be driven by supervisors' own social inclinations on the other hand their wish to build up excessively friendly associations with particular stakeholders. Most comprise of various small money charity aids help to local society causes (Guernsey 1999). If an organization's charitable work is connected to its economic area, the more noteworthy the organization's commitment to society will be. Aggregate investment in society can be much more actual than a by any one organization. However, organizations ought to have some social obligations. It should be efficiently pursued after in a manner that CRS will streamline the significance which can suggest corporate segment another arrangement of focused tool that will estimate the investment of assets. In the meantime, it can open a tremendously the additional intense approach to improve the world an improved place.

\section{Worker Welfare Fund}

In 1971 under the ordinance worker welfare fund (WWF) it was regulated that companies should take part and disclose their spending amounts towards worker welfare fund. It provided low charge to health, housing and other facilities for industrial workers and labors. Federal Government made the initial contribution towards the welfare fund then other private sectors started to raise funding. (Cox, Brammer et al. 2004) it is defined that companies should actively participate for taking care of employees and labors, moreover, (Cox, Brammer et al. 2004) and (Muller and Kolk 2010) studied widely used this dimension of CSR as a proxy.

\section{Worker's Profit Participation Fund}

Companies Profits Act, 1968 also known as Workers' Participation in profits. This is an act to provide a chance for workers to participate in the company's profit. Whereas it extended to the whole Pakistan, the national interest in terms to attain the uniformity with the clause (2) of article 131 requires the matters. Last studies frequently used different CSR dimensions in different aspects to check the relationship on firm's financial profits. But workers welfare fund is not merely found in the span of 2009-2014. However, this paper has an addition mark by introducing the measure of the other dimension of CSR regarding employee's benefit perspective in the form of WWF. It is empirically claim CSR practices among manufacturing sectors in Pakistan, as there was no study regarding to this CSR dimension from these sub-sectors as it pertains to manufacturing sector.

\section{Financial Performance}

Financial performance of manufacturing sector activities is measured by Federal Reserve Board. It measures the outcomes of a firm procedures and processes in economic terms. These consequences are mirrored in firms return on investment, return on assets and addition in value. Although, there are many researches on CSR actions among Pakistani's companies, it is same also conducted by (Margolis and Walsh 2001) to empirically measure the relationship amid CSR and CFP. (Lockett, Moon et al. 2006) set up a number of studies in the literature of finance which attempted to explore the firm's social performance and its profitability relation. The empirical connection showing the relationship of corporate social actions and corporate finance related performance, concentrated seriously, has led to clashing and mix results (Heal 2005). For this study corporate financial performance was taken as a dependent variable to reveal the financial benefits of the company to gain potential results by the application of CSR activities (Aras, Aybars et al. 2010) \& (Fauzi, Mahoney et al. 2007). At the opinion when partners slack trust on the company's act, the firm misplaces its basic support and 
client relation (Lee 2008). Customers quit purchasing items or go for legitimation,shareholder offer their bonds, representatives don't implement, and environment backer charge (Wood 1991), all of which straightforwardly influence firm performance. This result is as per the essential disagreement said by (Jensen 2002), that the sole goal of a corporate ought to be to boost its marketplace worth. As indicated by (McGuire, Sundgren et al. 1988) the included expenses may come about because of activities, for example, "making broad altruistic commitments, advancing group advancement arrangements, keeping up plants in monetarily discouraged areas also, setting up ecological insurance systems". These expenses may put a firm at a financial detriment contrasted with other, less socially dependable firms. Interestingly, others have contended the case for a positive affiliation. (McGuire, Sundgren et al. 1988) refer to the contention that a firm saw as high in social obligation may confront generally less work issues or maybe clients may be all the more positively arranged to its items. They (Bird, Hall et al. 2007), (Sturdivant 1977) and (Preston and O'bannon 1997) concluded for positive effect from organizations' CRS exercises on financial performance. (Fernandez 2002) investigate the relationship in the middle of CSR and financial ability by means of Valuation products (or companion products). (Pava and Krausz 1996) an association's CSR conduct is by all accounts an element that impacts banks and other institutional financial specialists' venture choices. Subsequently, a high CSR profile may enhance an association's entrance to wellsprings of capital.The public and private sector organizations can sustain profit and a can yield interests by improving and developing the CSR policies (Yusoff, Mohamad et al. 2013). It is stated that within the organizations CSR activities revealed more benefits than other activities in tough economic times (Lee, Singal et al. 2013). But some scholors not found specific, unilateral and even opposite turning relative in both CSR and CFP (Margolis and Walsh 2003). Likewise, it permits us to evaluate a clean causative impact of CSR on CFP. That concerns are liable to harm CFP appears to be instinctive and is broadly documented (Konar and Cohen 2001). In the past works, the papers that are nearest to putting forth causal declarations are (Dowell, Hart et al. 2000),(Lev, Petrovits et al. 2010) and (Preston and O'bannon 1997). Despite the fact that the causality between these two is yet not clear, empirical studies demonstrate a simultaneous relationship-collaboration in the middle of CSR and financial execution (Weber 2008). (Newgren, Rasher et al. 1985) take a firms' financial performance with respect to an industry performance and located a negative relationship. The results (Tsoutsoura 2004) indicates that the relationship sign of the CSR and CFP is statistically significant and positive, it supports the veiw that the firms who are involved in responsibilities can be associated with the bottom-line series of benefits.
Two forms of empirical educations between CSR relationship and FP were essentially comprised in history. The first empirical study related to check the relationship between SR and FP was published by Narver in 1971. Abnormal return has mixed results of impact. (Wright and Ferris 1997) reported negative relationship; (Posnikoff 1997) discovered a progressive relationship; (Teoh, Welch et al. 1999) showed no relationship. In this observation (Mulyadi and Anwar 2012) there is no noteworthy relationship in the middle of CSR and benefit.(Abbott and Monsen 1979) and (Alexander and Buchholz 1978) has supported no specific link among CSR exercises and related financial performance. The relations in the middle of CSR and FP are for the most part uncertain, yet significant relations in the two have been accounted for in the greater part of the studies (Margolis and Walsh 2003) suggesting an instrumental introduction of CSR activities. An influential introduction to CSR recommends the arrangement of the social objective with the trade objective someplace CSR is well-thought-out as a key instrument to advance the monetary target of the organization. There is likewise no noteworthy relationship in the middle of CSR and firm esteem. Type two study measures the relation between long term financial performance and corporate social performance has too explored jumbled outcomes. (Cochran and Wood 1984) delivered a significant positive connection between obligation in the wake of shade the age of assets. This study (Aupperle, Carroll et al. 1985) not discovered noteworthy connection between a company's adjusted risk of assets and corporate social act. The impact is pathetic for organizations with more elevated amounts of CSR, proposing that marginal returns decreases with the CSR source (Flammer 2015) . It is not surprising to see inconsistency of researchers effects after the relationship of these studies between CSR and profitability presentation, according to for example (Aupperle, Carroll et al. 1985) and (Waddock and Graves 1997) these also have concluded mixed results, to found positive, negative, no or neutral relations randomly. In past there found a positive linkage of financial performance (McGuire, Sundgren et al. 1988). In light of following studies (Cochran and Wood 1984) and (Waddock and Graves 1997) it concluded that CSR is a helping hand to improve FP. (Marsat and Williams 2011) examination of the link between firms' CFP and ECSR concerns ought permit room for both immediate and indirect impacts to catch the worldwide effect of ECSR concerns. The researchers (McWilliams and Siegel 2001) founded neutral impact of CSR on financial performance, these misspecifications in results may be due particular flawed existing empirical analysis and econometric techniques of assessing the corporate social responsibilities and financial performance. Study examines that the results are reliable with the mind that CSR actions improve performances (Simpson and Kohers 2002) and (Harjoto and Jo 2008), it fact towards that CSR can effect both returns and cost functions. It finds (Scholtens 2008) that 
monetary performance by and large terms leads social execution a great deal more regularly as compare to other way around. While, firms engage in CSR increase even more revenues than cost increase. Although the FP literature is rich in studies regarding CSR, (Gallardo-Vázquez and Sanchez-Hernandez 2014) determined set of corporate social responsibility indicators provide useful and simple regulation for implementing the responsible practices to upgrade firms competitive success which ultimately leads to financial benefits.

\section{Return on Assets}

Return on assets is an income which a company generates from its total assets which the company has invested. These generated incomes vary company on the basis of capital intensity which actively participates in firms' financial performance. The study used the proxy of return on assets (ROA) to reflect the financial performance of the company (Orlitzky, Schmidt et al. 2003) and (Teoh, Pin et al. 1998). The effect of CSR with accounting performance (for instance ROA) is a long-standing yet at the same time uncertain question. ROA is reliably guaranteed to be a real measure of FP (Berman, Wicks et al. 1999) and (McGuire, Sundgren et al. 1988). Dissimilar to other accounting methods, for example, return on value or profit for sales, ROA is not influenced by the variance level of influence existing in firms. Since ROA is absolutely related by the stock value, with a high ROA suggests worth creation for stakeholders. Besides, in resource overwhelming organization for example, the assembling firms, ROA is a superior pointer of firm actions. In a current study, (García and Armas 2007) discovered a significance link in organizations' CSR exercises and return on assets (ROA). Productivity is the organization's capacity to generate a yield that would maintain short span and long span development. Increasing the extent of firm productivity must be the more prominent the level of social exposure (Hackston and Milne 1996). (Griffin and Mahon 1997) who took a singal corporate and locate a constructive relationship in the middle of ROA and corporate social obligation, furthermore by (Dooley and Lerner 1994), who practice it as an association's ROA in respect to the business normal ROA and found the projected positive linkage. It (Lioui and Sharma 2012) evaluates the effect of natural corporate social obligation (ECSR) on Corporate Financial Performance (CFP) entertained by ROA. As indicated by administration literature summerized by (Margolis and Walsh 2003) more than 120 researches pretaining in 1971 and 2001 look at the observational connection in the middle of CSR and money related execution, and the outcomes are to a great extent uncertain. Other financial measures not does merely reflection as return on assets does. (Parsa and Deng 2008) which provide information of U.K demonstrate that a significance modification in organization size prompts significant and affirmative influence in extent of corporate social obligation exposure. Return on assets (ROA) is adopted as dependent variable to represent firm's profitability performance. This proxey is employed by number of studies to signify short term profitability (Lee, Singal et al. 2013). The outcomes exhibit that the investment of CSR for manufacturing and non-manufacturing enterprises has no positive relationship with the ROA (Lin, Yang et al. 2009). ROA is used as a dependent variable which predicts a curved relationship in the middle of CSR and CFP (Flammer 2015). CSR have not much beneficial outcome on financial performance of a transient period, (Lin, Yang et al. 2009) it offers an exceptional long term financial advantage. (Banz 1981) explored the minor firm impact which proposed that not large corporations, all things considered, crop more estimated stock profit than bigger firms. Interestingly, as indicated by (Ball 1978), minor corporations are risky than bigger corporations that have a tendency to give additional information material to the economic of the society. The study (Aupperle, Carroll et al. 1985) located no significant relative amid corporate social performance and an organization's risk adjusted ROA. It find (Lioui and Sharma 2012) environmental CSR concerns and strengths have a negative association with CFP measured by ROA. (Teoh, Welch et al. 1999) and (Aly, Simon et al. 2010) established that organization profitability depicting no impact over the corporate social responsibility. In contrast, (Waddock and Graves 1997) also like number of other studies detected positive significant relation CSP index and measuring of performance like ROA in the subsequent year. The study (Tsoutsoura 2004) also revealed ROA is statistically significance correlated with social index. It defines the statistically significant result organization size on the degree of CSR (El-Bannany 2007) and (Hossain and Reaz 2007). It is presumed that organization profitability positively affects corporate social obligation expenditure (VINTILǍ and Florinita 2013).

\section{Return on Equity}

Return on equity measures a firm's profitability by depicting how much an organization generates the profit with the invested amount by shareholders. But it does not add preferred shares, it is also can call as "return on not worth", it is useful and influencing for company's profitability. In literature review (Belkaoui, Association et al. 1978) and (Hossain 2000) found a very positive and strong impact of return of equity on corporate financial performance. When an organization increases its debts unreasonably, the company's return on equity may dwindle since the marketplace sector observes the organization as excessively risky (Brealey). (McGuire, Sundgren et al. 1988) message that, there finding is most grounded for accounting base measures of ROE. This is reason to the fact the higher level of profitability of a firm, spared a large amount for social welfare and donation which in result leads to high CSR. According to (Haniffa and Cooke 2005) profit generating organizations are consistently profound to report their CSR and highlight firm's performance in the 
society eyes (Veronica Siregar and Bachtiar 2010). It (Tsoutsoura 2004) argued ROE is no significant as it is used in same direction to measure the profitability. While, KLD depicts less strong, but it is still significant. For accounting base measuring of financial position the company, for the measure of return on equity (ROE) the data is obtained for three years (Orlitzky, Schmidt et al. 2003) \& (Teoh, Pin et al. 1998). (Lee and Park 2009) stated effects of CRS performance independently for restuarent and clubs organizations regarding ROE. The higher profitabilty encourage management to deliver more related information to deminstrate its capability to take full advantage of the shareholder's worth and to improve its managerial compensation (Singhvi and Desai 1971).

\section{Earning Per Share}

It is an earning amount per outstanding share on the company's common stock. Before the calculation of earnings per share (EPS), the amount of preferred is deducted. Its earnings per share value motivate the investors to invest more. A positive increase in earnings per share is an obvious to increase in corporate social responsibilities. It is mean firms social performance abilities increase with the increase in the level of earnings per share. Both remained in increasing change. Earnings per share depicts the increase in firm's social performances (Simpson and Kohers 2002) and (Afza and Mirza 2011) are significant and positive concern can show positive correlation with firm's social performance, it is seen a significant and positive coherent between EPS, However, it revealed the increase in financial performance in perspective of earning per share can lead to high corporate's social responsibilities, this is because the spared finance motivate to spend for social performance.

\section{Research Methodology}

This study is directed to deliver an indication on the association of CSR and financial enactment of Food, Automobile and Chemical sectors firms. These sectors shed well-lit how Normality test, Descriptive statistics and Multiple Regression Analysis and other different methodologies are used to conclude the relation between CSR and firms performance. It exemplifies the techniques and sample design. Research tools, Variables dimensions, well designed models, means of data assemblage, analysis the data and time span of this study. The research tools support the literature. To analysis the CSR and firm performance relation the secondary data from the internet streamline annual reports of the chosen sample has been used.

\section{Research Problem}

The effective implication of CSR practices in developing countries' economies is under debate from last many decades. Food, Chemical and automobile sectors are more sensitive to the health of population of country. It is observed that generally companies are reluctant to follow the standards and requirements of CSR. This leads adversely to the interest of public, damages the organizational cultures and causing overall societal environment of the country. The management of such organizations either has much lesser realization of importance of CSR or has been conservative in this approach. In this concern, this research has the privilege to add more to these grounds.

\section{Research Design}

Population

In this regard, to empirically explore the corporate social responsibility activities effect with the financial performance of the firms. The population of the study involve all three sub-sectors (food, automobile \& chemicals) of the manufacturing sector with total of 104 industries segregated 54, 16 and 34 respectively of chosen sub-sectors listed under Karachi Stock Exchange (KSE).

\section{Data and Sample Size}

In accordance to explore the link between corporate social responsibility and financial performance in Pakistani context, to check the acquiescence level of CSR for manufacturing sectors firms the sample size of 56 non-financial industries with balanced have been selected on the accessibility of the data information of this study was the yearly reports of the picked sub sectors; listed under Karachi Stock Exchange (KSE). The panel estimation has connected for the year 2009-2014. The sample observations for this study are $56 * 6=336$. Just those sub-sectors industries are chosen which stand recorded amid the spell of 2009 to 2014, and uncover the particulars of CSR in their yearly financial reports which were downloaded from the sites and are analyzed appropriately. In Pakistan, manufacturing sector is leading one among non-financial sectors.; for the period of 2006-2009, the mentioned CSR elements and financial proxies were used by (Ehsan and Kaleem 2012).

From whole population we randomly took following manufacturing sectors data as sample.

- Food sector

- Chemical sector

- Automobile sector

\section{Growth in Food Sub-Sector}

In Pakistan context, the food industry is developing at a quick pace mostly due to the increment in populace, urbanization and reasonably rising family unit spending. As indicated by the 2012-13 yearly report of the Stat Bank of Pakistan (SBP), the nourish business in Pakistan developed by 9.5\% in FY 2013, up from 5.9\% in FY 2012. 
Another report by SBP demonstrated that the nourishment and drinks industry which has a balanced weight of $17.6 \%$ in large manufacturing sector developed by $7.78 \%$ in the initial nine months of the current financial year. This pattern is likely to proceed as both national and multinational organizations are growing their networking system keeping expanding their market share. Not surprising, an examination related to financial reports of food industry demonstrates an increment in their net profits and sales.

\section{Growth in Chemical Sub-Sector}

The chemical sector adds to around $6.71 \%$ to the large scale manufacturing, and is likewise a noteworthy source of tax income for the government separated from contributing altogether in making job opportunities. The Economic Survey 2013-14 demonstrates that the development of $5.55 \%$ has been enlisted in the manufacturing amid nine months of current financial contrasted with the development of 4.53 percent in same period a year ago. Manufacturing is the most vital sub-sector of industrial part containing 64.92 percent offer in the industrial area.

\section{Growth in Automobile Sub-Sector}

An overall upsurge in automobile deals has demonstrated that the Pakistani auto business sector has enough space to cater new participants as the conceivable interest of value variations astoundingly exist here, which has been hampering the nation's business sector development by low quality models. With the accessibility of some recognized variations, auto partners are hurrying to get the corolla's Toyota's new models, which controlled autos deals enormously in this year. It could be found by this that auto mobile sector is participating by 52.50 percent pushed general Large Scale Manufacturing businesses yield up by 4.67 percent for July, contrasted with same month in a year ago.

\section{Conceptual Framework}

This study addressed the effect and causal linkage of CSR with the financial variables that the scholars and theoretical history attributed to be positively and negatively related to conceptual model.

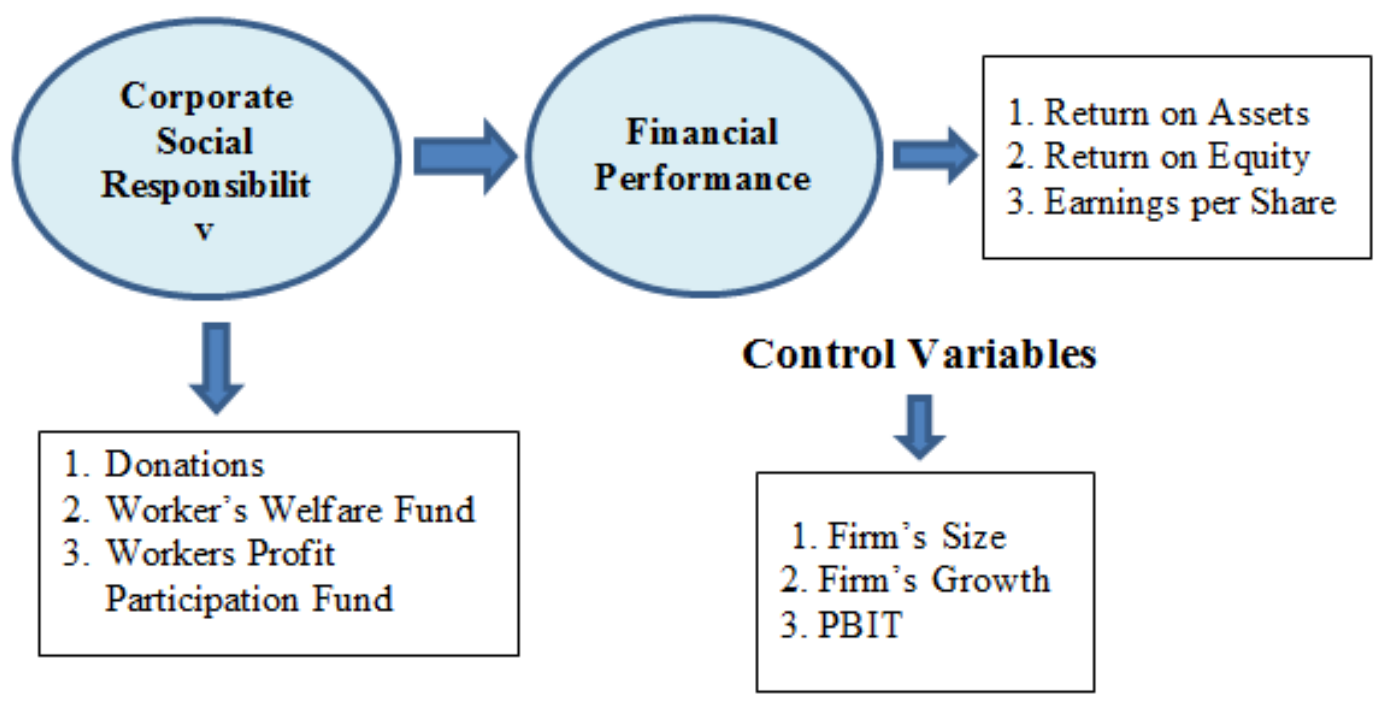




\section{Variables}

Dependent Variable: Financial Performance

Three intermediaries have used to gauge the monetary execution of manufacturing sub-sectors industries. The accompanying accounting figures are taken by the yearly reports of these industries. ROA shows return on assets which are figured as ratio of profit after tax divided by total assets. ROE describes to return on equity which is figured as proportion of profit after tax by dividing share capital. EPS computed to the acquiring profit per share; it characterizes the business sector estimation of the share toward the end of financial year.

$$
F P=R O A+R O E+E P S
$$

Independent Variable: Corporate Social Responsibility

Three proxies are measuring the corporate social responsibility independent variable of this study, it is characterized as industries' obligation to perform good in enhancing, advancing and for the improvement of the societal prosperity, ecological manageability, construct watch over representatives and different partners, social gatherings, suppliers, clients, shareholders and Government powers far from their legitimate, social and monetary adherence. If there should arise an occurrence of Pakistan all industries report their different social concerns like (charity, laborers welfare reserve, environment ensured programs, society improvement ventures, morals, learning programs, medical facilities, wellbeing, service centers and so on.)

\section{CSR $=$ Donations + Worker's Welfare Fund \\ + Workers profit Participation Fund}

\section{Control Variables}

\section{Sales}

A company is rapidly growing as compare to its peers to the flourish economy. However, it is not hard and fast to define firm's growth. Generally, its growth is based on the capability to enhance annual revenues by adding more over the average sustained period. Firm's growth (FG) has to demonstrate over a couple of years. Following studies (Nazir and Afza 2009) and (Ruf, Muralidhar et al. 2001) used sales a financial dependent variable proxy for growth in firm's sales. It is the measure of firm's increasing sales value on annual basis, with position to change in its last year's sales. In many former research studies (Ullmann 1985) and (Blazovich and Smith 2010) firm growth is taken as control variables which is found an important contributing factor while pursuing the effects of social as well financial performance of the firms. Past exploration has considered yearly sales (Fombrun and Shanley 1990). Buyers pay consideration regarding the CSR accounts of the organizations, including mostly for their society activities, while buying (Gildea 1994) and (Owen and Scherer 1993) these factors contribute to firm growth.
Profit before Interest and Tax

It is important to tell the investors the company's profitability efficiency. Profit before interest and tax (PBIT) matrix is very useful, it is found in the survey of 200 marketing seniors' managers when the $91 \%$ results were in favor. It is also known as bottom line net earnings or net income is the measure of a ventures' profitability after bearing all accounting costs. This figure is an appealing hand of the company for their shareholders. Reinforces the relation (Bouchard 1976) between CSR and firms profitability. (Husted 2003) at the point when organization center their community activities in societies and on their zone of operation, they earn profit from a socially dependable image among their workers and the around society. Evidence proposes active environment administration improves company's market worth (Klassen and McLaughlin 1996) image, and firms' profitability (Gil, Jimenez et al. 2001) and (Miles and Covin 2000). (Florinita 2011) institute a positive association in corporate social obligation expenses and firm financial presentation. Past examination has set up that well administration values of organizations prime to upgraded profitability(Black and Khanna 2007).

\section{Total Assets}

The firm's optimal size in the given industry, with a specific given time brings per unit lowest cost of production output. In the industries performance and decision to follow theoretical models the control variable is used (McWilliams and Siegel 2001) and (Chih, Chih et al. 2010). It positively linked with CSR and FP, and coefficient also become more consistent to some extent in previous studies. Thus, it is estimated that the coefficient of total assets in CSR regimes all are found positively significant (Wu and Shen 2013), coefficient of this variable is resulting alike to those of former empirical outcomes with few potentials. This is fortune (Siegel, 2000) supports the strong positive specification of size of the firm on the corporate social performance; it is stated as control variable. Total assets (Waddock and Graves 1997) as indicator of corporate size. (Uwuigbe, Uwalomwa et al. 2011) recognize a noteworthy positive link occurs with the organization size and the participation of corporate social actions. Along these lines, basically suggests that the size of an organization, the more they will invest. It (Goddard, Molyneux et al. 2004) and (Bonin, Hasan et al. 2005) justifies in the literature the results are related to those where assets have commonly a positive impact. Hence, in the light of (Sharif and Rashid 2014) consequences that it is very strong and known relationship is found between CSR and the size of the firm. (Macey and O'hara 2003) also shown the direct relation. With size of investment and profit generated. It means the greater contribution in firm social actions, ethics, moral values and norms.

\section{CNTL: Firm Size + Firm Growth + Profit before interest and Tax}




\begin{tabular}{|c|c|c|c|}
\hline Variables & Measurements & Abbreviations & References \\
\hline \multicolumn{4}{|c|}{ INDEPENDENT VARIABLES (Corporate Social Responsibility) } \\
\hline $\begin{array}{c}\text { Corporate Social } \\
\text { Responsibility }\end{array}$ & $\begin{array}{l}\text { Donation, Worker Welfare Fund, Workers } \\
\text { Profit Participation Fund }\end{array}$ & CSR & (Andrikopoulos, Samitas et al. 2014) \\
\hline \multicolumn{4}{|c|}{ DEPENDENT VARIABLES (Financial Performance) } \\
\hline ROA & $\begin{array}{c}\text { Earnings after interest and taxes/Total } \\
\text { assets }\end{array}$ & ROA & (Yusoff, Mohamad et al. 2013), \\
\hline ROE & Earnings after taxes/ Total Equity & ROE & $\begin{array}{c}\text { (Lee, Singal et al. 2013), (Sharif and Rashid } \\
\text { 2014), }\end{array}$ \\
\hline EPS & $\begin{array}{l}\text { Net income after preferred dividend/ No. } \\
\text { of outstanding shares }\end{array}$ & EPS & (Ehsan and Kaleem 2012), \\
\hline \multicolumn{4}{|l|}{ CONTROL VARIABLES } \\
\hline Firm Size & $\begin{array}{c}\text { Size of the firm } \\
\text { (log of total assets) }\end{array}$ & SIZE & $\begin{array}{l}\text { (Bonin, Hasan et al. 2005), (Wu and Shen } \\
\text { 2013), (Deng, Kang et al. 2013) }\end{array}$ \\
\hline Firm Growth & Growth in sales for firm & GROW & (Ehsan and Kaleem 2012) \\
\hline $\begin{array}{l}\text { Profit before interest and } \\
\text { Tax }\end{array}$ & Profit before interest and Tax & PBIT & \\
\hline
\end{tabular}

\section{Analysis, Results and Discussions}

For analyzing the relationship of corporate social responsibilities with the firm financial performance, for this purpose quantitative techniques have been taken. With panel least square, multiple regression methods to measure the effect of corporate social responsibilities as an independent variable, with financial measuring of dependent variables are return on assets, return on equity and profit before interest and tax and for controlling the other effects firm size, firm growth and profit before interest and tax are control variables. Descriptive statistics additionally applied to measure the quality of secondary nature data and these tools are estimated through regression models.

\section{Descriptive Statistics}

Descriptive results indicate a summary about descriptive statistics of variables the independent, dependent and control is given in table 1. This indicates the average values of discuses variables used. Below in table 1 Descriptive data analysis, the Independent variable i.e. corporate social responsibilities, dependent variable i.e. return on assets, earnings per share and return on equity and control variable i.e. firm size, firm growth and profit before interest and tax.

Table 1. Descriptive Analysis

\begin{tabular}{|c|c|c|c|c|c|c|c|c|c|}
\hline & ROE & ROA & EPS & DN & FZ & GOW & PBIT & WPPF & WWF \\
\hline Mean & 0.190 & 0.0789 & 21.882 & 9038153. & 9.608 & 9.672 & 1.049 & 78141579 & 32307806 \\
\hline Median & 0.163 & 0.060 & 5.857 & 1417562. & 9.580 & 9.631 & 1.974 & 12707903 & 5360869. \\
\hline Maximum & 6.241 & 1.173 & 458.467 & 1.313 & 10.937 & 10.935 & 2.254 & 1.784 & 6.634 \\
\hline Minimum & 3.382 & 1.048 & 51.351 & 0.000 & 7.306 & 7.346 & -2.776 & 0.000 & 0.000 \\
\hline Std. Dev. & 0.575 & 0.150 & 63.511 & 1.962 & 0.635 & 0.701 & 2.703 & 2.129 & 83190770 \\
\hline $\begin{array}{c}\text { Jarque-Bera } \\
\text { Probability }\end{array}$ & $\begin{array}{c}30718.16 \\
0.000\end{array}$ & $\begin{array}{c}7437.969 \\
0.000\end{array}$ & $\begin{array}{c}9366.428 \\
0.000\end{array}$ & $\begin{array}{c}3229.894 \\
0.000\end{array}$ & $\begin{array}{c}3.06250 . \\
031\end{array}$ & $\begin{array}{c}18.4131 \\
0.010\end{array}$ & $\begin{array}{c}15424.6 \\
0.000\end{array}$ & $\begin{array}{c}17364.03 \\
0.000\end{array}$ & $\begin{array}{c}12505.20 \\
0.000\end{array}$ \\
\hline Observations & 336 & 336 & 336 & 336 & 336 & 336 & 336 & 336 & 336 \\
\hline
\end{tabular}

The description of all variables' dimensions are indicated shown in above table with their averages, ranges and probabilities, range of donations 0.000000 to 1.313859 from minimum to maximum, the 9038153 value of mean showing the less participation towards the society than other two means of funds related to workers, worker profit participation fund 1.784409 and worker welfare fund $0-6.634808$ showing from minimum to maximum and mean values 78141579 and 32307806 respectively. It clearly describes that manufacturing sector chosen industries are more tend to contribute towards the workers' profit participation fund, and the maximum value is of workers welfare fund. $0.190902 \mathrm{ROE}$, 0.078938 ROA and EPS 21.88274 mean values; it shows CSR has more influence on EPS. ROE and ROA both positive $3.382000,1.048000$, minimum and maximum values are 6.241000 and 1.173000. Financial performance dimension with distinct range 51.35100 to 458.4670 , control variables mean 9.608992, 9.672098 and 1.049296 size, growth and PBIT respectively. Moreover, the Jarque-Bera probability $<0.05$ was showing data normality. 


\section{Regression Analysis}

This analysis applied to check the impact of social actions of the firm on the financial performance measurements regression models applied in which the execution of CSR, three other dimensions are used for measuring the performance of manufacturing sub-sectors industries, performance estimators i.e. EPS, ROA and ROE, control variables i.e. firm size (log of assets), firm growth (log of sales) and profit before interest and tax.

For the research model three hypotheses are figured. The performance of return on assets is measure by using corporate social performance including all control variables, in second hypothesis return on equity is as dependent indicator affected by CSR and adding control variables, the third one hypothesis is measured with EPS dependent variable the corporate social and financial performance associations are checked. The panel least square techniques include the multiple regressions for results and Durbin-Watson stat used for autocorrelation.

Relationship of Corporate Social Performance and Financial Performance relating to ROA

\section{Results for Model (I)}

$$
\begin{gathered}
R O A \text { it }=\beta 0+\beta 1(\mathrm{DN} \text { it })+\beta 2(\mathrm{WWF} \text { it) }+\beta 3(\mathrm{WPPF} \text { it }) \\
+\beta 4(\mathrm{FG} \text { it })+\beta 5(\text { SIZE it })+\beta 6(\mathrm{PBIT} \text { it })+\varepsilon i t
\end{gathered}
$$

H1a: Donations has significant positive impact on return on assets.

H1b: Worker Welfare Fund has positive significant impact on return on assets.
H1c: Worker profit participation fund has significant positive impact on return on assets.

The panel least square techniques by using fixed effect model for testing the above mentioned hypotheses are given in the below table by using multiple regression method, Durbin-Watson stat. The model fitness, probabilities and coefficient of all variables are mentioned in the given below table.

Table-I the regression techniques results shows the donation t-value -1.632449 negative and 0.1035 statistically insignificant which is $\mathrm{p}<0.05$ with value -7.9590 of coefficient. Worker profit participation and worker welfare fund both have 4.992861 or 2.573894 positive and same $0.0000,0.0105$ statistically significant impact on firm ROA respectively with the values of coefficient 5.3989 and 2.9085. In light of above interpretation $\mathrm{H} 1 \mathrm{a}$ is rejected and $\mathrm{H} 1 \mathrm{~b}$ and $\mathrm{H} 13$ are accepted. Control variables profit before interest and tax and firm growth are positive significant as it $\mathrm{P}<0.05$, firm size insignificant with ROA 0.0715 and its -1.808355 negative and which ought positive t-statistics $>2$ or 2 . In addition, Durbin Watson 1.91926 depicts the no autocorrelation among variables; F-statistic 0.00000 shows the outcome of these tests is appropriately good. The value is $47 \%$ of R-square narrating the ROA deviation due to corporate social responsibility.

Relationship of Corporate Social Performance and Financial Performance relates to ROE.

Table-I

\begin{tabular}{|c|c|c|c|c|}
\hline Variable & Coefficient & Std. Error & t-Statistic & Prob. \\
\hline DN & -7.9590 & 1.26348 & -1.632449 & 0.1035 \\
\hline WPPF & 5.3989 & 0.01047 & 4.992861 & 0.0000 \\
\hline WWF & 2.9085 & 0.04974 & 2.573894 & 0.0105 \\
\hline PBIT & 7.6932 & 0.04875 & 9.288765 & 0.0000 \\
\hline GOW & 0.0437 & 0.01246 & 2.552101 & 0.0112 \\
\hline FZ & -0.0358 & 0.11793 & -1.808355 & 0.0715 \\
\hline C & 0.0169 & 0.0826 & 0.0471 & 0.0561 \\
\hline R-squared & 0.472649 & & & \\
\hline Adjusted R-squared & 0.259384 & & & \\
\hline Durbin-Watson stat & 1.91926 & & & \\
\hline F-statistic & 20.55440 & & & \\
\hline
\end{tabular}




\section{Results for Model (II)}

\section{ROE it $=\beta 0+\beta 1(D N$ it $)+\beta 2($ WWF it $)+\beta 3($ WPPF it $)$ $+\beta 4($ FG it $)+\beta 5$ (SIZE it) $+\beta 6($ PBIT it) $+\varepsilon i t$}

H2a: Donations has significant positive impact on return on equity.

H2b: Worker Welfare fund has significant positive impact on return on equity.

H2c: Worker profit participation fund has significant positive impact on return on equity.

In table-II the regression values consequences the influence of corporate social performance on the return on equity, worker welfare fund $t$ value 3.125189 is positive and 0.0019 significant $p<0.05$ statistically the workers profit participation fund also has positive 5.569930 and statistic significant 0.0000 effect of corporate social responsibility on return on equity, coefficient value 2.290349, but the donation towards society outcomes are negative insignificant with the negative value -2.993847 of beta. In the evidence of above results we rejected donations H2a. Worker welfare fund or workers profit participations hypothesis on the basis of positive significant results are accepted. Except of firm size which is statistically negative and insignificant -2.238820 and $0.0258, \mathrm{p}<0.05$ all other control variables are depicting positive and significant showing positives coefficients value. F-statistics 0.000000 shows fitness of model, Durbin-Watson figures 2.03709 depicting no autocorrelation, the value of coefficient determination indicate variation of $60 \%$ in return on equity due to the independent variable with 0.263525 adjusted R-square.

Relationship of Corporate Social Performance and Financial Performance relating to EPS

\section{EPS it $=\beta 0+\beta 1(D N$ it $)+\beta 2(W W F$ it $)+\beta 3($ WPPF it $)$

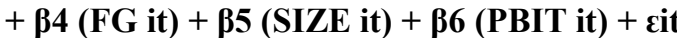

H3a: Donations has significant positive impact on earnings per share.

H3b: Worker Welfare Fund has significant positive impact on earnings per share.

H3c: Worker Profit Participation Fund has significant positive impact on earnings per share.

Table-II

\begin{tabular}{|c|c|c|c|c|}
\hline Variable & Coefficient & Std. Error & t-Statistic & Prob. \\
\hline DN & -2.993847 & 1.39752 & -1.613670 & 0.1076 \\
\hline WPPF & 2.404865 & 0.03761 & 3.125189 & 0.0019 \\
\hline WWF & 2.290349 & 0.00792 & 5.569930 & 0.0000 \\
\hline PBIT & 3.183610 & 0.08986 & 9.892135 & 0.0000 \\
\hline GOW & 0.206953 & 0.01937 & 3.191414 & 0.0016 \\
\hline FZ & -0.164982 & 0.02963 & -2.238820 & 0.0258 \\
\hline C & 0.2718 & 0.0025 & 0.5439 & 0.5872 \\
\hline R-squared & 0.596715 & & & \\
\hline Adjusted R-squared & 0.263525 & & & \\
\hline Durbin-Watson stat & 2.03709 & & & \\
\hline F-statistic & 9.092510 & & & \\
\hline Prob(F-statistic) & 0.000000 & & & \\
\hline
\end{tabular}

Table-III

\begin{tabular}{|c|c|c|c|c|}
\hline Variable & Coefficient & Std. Error & t-Statistic & Prob. \\
\hline DN & 4.584789 & 0.03593 & 2.132649 & 0.0337 \\
\hline WPPF & 1.453086 & 0.00465 & 3.051872 & 0.0025 \\
\hline WWF & 2.013864 & 0.01943 & 2.259221 & 0.0245 \\
\hline PBIT & 2.333975 & 0.59264 & 6.251098 & 0.0000 \\
\hline GOW & 34.17271 & 0.39271 & 4.547930 & 0.0000 \\
\hline FZ & -14.66983 & 1.02894 & -1.718034 & 0.0867 \\
\hline C & 0.129453 & 0.474326 & 1.395742 & 0.0427 \\
\hline R-squared & 0.752902 & & & \\
\hline Adjusted R-squared & 0.188366 & & & \\
\hline Durbin-Watson stat & 1.94501 & & & \\
\hline F-statistic & 12.33929 & & & \\
\hline
\end{tabular}


In Table-III the regression values results for positive influence of corporate social actions on earnings per share, all dimensions of independent variable donations $t$ statistics $>2$ showing positive and 0.0337 statistically significant the other dimensions are t-statistics 3.051872 and 2.259221 which greater $>2$ giving the positives and $0.0025,0.0245$ significant results respectively, the coefficient value of donations is comparatively more greater 4.584789 as to others. In light of all positive and significant results we accepted $\mathrm{H} 3 \mathrm{a}, \mathrm{H} 3 \mathrm{~b}$ and $\mathrm{H} 3 \mathrm{c}$ hypothesis are accepted. Firm growth and profit before interest and tax are positively significant in order of 4.547930 and 6.251098 but size -14.66983 coefficient results in negative and insignificant. Table-III results $p$ value 0.000000 shows the appropriateness of applied F-statistics. The $75 \%$ coefficient determination demonstrates the variation in earnings per share occurring due to corporate social responsibility. Durbin-Watson 1.94501 depicts no autocorrelation.

\section{Findings of Research}

The empirical investigation between the relationship of corporate social and financial performance by ROA, ROE and EPS of manufacturing sector industries was developed. One by one the variables regressed. The descriptive analysis, panel least square and multiple regression analysis reported to which extent Pakistani manufacturing industries regulated the social responsibilities considering the duration from 2009-2014.

The descriptive analysis, panel least squares and multiple regression estimation gave results for the nature and significance of relationship. The corporate social responsibilities have significant and positive relationship with financial performance on accounting base indicators. The deepest concern of corporate social responsibilities is to serve the society interest. This relationship demonstrates that the manufacturing sub-sectors including, food, chemical and automobile are performing due admirably because of the focus on the application of corporate social practices.

Social responsibility policies have significant and positive association with firm execution and source to upgrade in ROA, ROE and EPS values. This independent relationship involves the donation to the society, worker welfare fund and workers profit participation fund. This is higher concentration on the grounds that Pakistani manufacturing firms are voluntarily taking participate in social actions to influence the financial performance of the firm. The need for organization social performances is highly related with firm's financial performance. The firms with social responsibilities have higher level of compliance to enhance financial performance.

\section{Conclusions}

This study empirically investigated the corporate social practices and firm financial performance relation of Pakistani manufacturing sector, this study accomplishes its prime purpose by analyzing the relation between these variables. To ascertain the relation between them 56 manufacturing industries listed under Karachi stock exchange are chosen on the data accessibility basis. From the annual reports of these industries the data for the time span 2009-2014 was gathered. The independent variable is with three dimensions donation towards society welfare, worker welfare fund for providing them low cost facilities and worker profit participation fund in firm's profit and transparency of all mentioned proxies.

After the advancement and measure of CSR the Dependent variable is measured by ROA, EPS and ROE are analyzed through applying panel least square techniques, descriptive statistics and regression models. Additionally control variables firm growth, firm size and profit after tax are presented to control the impact of the statistic model. In this research the relationship of corporate social responsibilities and firm financial performance is tested. The regression association of the variables is statistically recorded. Moreover the descriptive table also demonstrates the relative significance of every variable by posting the variations and means.

The results argue that the CSR and accounting base financial measures are associated on the basis of significance and positive results. The results infer that corporate social practices incline to higher performance as far as donations has negative insignificant but worker welfare fund and worker profit participation fund has positive significant impact on return on assets, all CSR dimensions have positive significant impact on earnings per share and except donations other two proxies have positive and significant impact on return on equity. Every proxy of firm's social performance has tested to ascertain their impact on firm financial performance. These proxies have significant impact on financial performance as demonstrated by the estimations of probabilities, coefficients and Durbin Watson to check the multiple regressions in the data analysis tables.

The outcomes expose that the social responsibility of Pakistani organizations is described with the involvement in society for betterment and development programs and working for the welfare of the employees having good effectiveness impact on firm's image. The organizations have to face public confrontation while ignoring the related aspects, avoiding the responsibilities of stakeholders or due to unawareness or applying the weak strategies or policies of CSR. The principle purpose of corporate social responsibilities in Pakistan is to participate for the advantages of internal and external stakeholders and in return firms gain long term financial benefits. The manufacturing sector industries fairly transparent their social related actions.

Like other evolving and developed nations also in Pakistan corporate social responsibility structure is a 
device to assess the financial performance and to look the interest of stakeholders of both non-financial and financial firms. To successfully actualize corporate social responsibilities in manufacturing industries recommended performing these obligations voluntarily considering it as an investment instead of cost. The Govt. and firms' shareholders should actively participate in the need for more consistent results for the benefits of the country.

\section{Study Limitations}

This study has few limitations, it is conducted by using simply three sub-sectors of manufacturing sector in Pakistani context, the data consists of 56 industries of food, chemicals and automobile, as annual reports are collected on the basis of 2009-2014 years due to unapproachable data, also scarcity of time and unavailability of resources, so through put on these the prevailing gap can be bridge. Despite these restrictions we trust this can serve as avenue or various territories for future exploration. However the future results may test our findings with some different point of view.

\section{REFERENCES}

[1] Abbott, W.F. and Monsen, R.J. (1979). On the measurement of corporate social responsibility: Self-reported disclosures as a method of measuring corporate social involvement. Academy of Management Journal, 22(3), 501-515.

[2] Abu-Sulayman, A. (1976). The Economics of Tawhid and Brotherhood', Contemporary Aspects of Economic Thinking in Islam, American Trust Publications, Indianapolis, IN.

[3] Afza, T. and Mirza, H.H. (2011). Do mature companies pay more dividends? Evidence from Pakistani stock market. Mediterranean Journal of Social Sciences, 2(2), 152-161.

[4] Alexander, G.J. and Buchholz, R.A. (1978). Corporate social responsibility and stock market performance. Academy of Management Journal, 21(3), 479-486.

[5] Aly, D., Simon, j. and Hussainey, K. (2010). Determinants of corporate internet reporting: evidence from Egypt. Managerial Auditing Journal, 25(2), 182-202.

[6] Andrikopoulos, A., Samitas, a. and Bekiaris, M. (2014). Corporate social responsibility reporting in financial institutions: Evidence from Euronext. Research in International Business and Finance, 32, 27-35.

[7] Angelidis, J.P. and Ibrahim, N.A. (1993). Social demand and corporate supply: a corporate social responsibility model. Review of Business, 15(1), 7-10.

[8] Aras, G., Aybars, a. and Kutlu, O. (2010). Managing corporate performance: Investigating the relationship between corporate social responsibility and financial performance in emerging markets. International Journal of Productivity and Performance Management, 59(3), 229-254.
[9] Arlow, P. and Gannon, M.J. (1982). Social responsiveness, corporate structure, and economic performance. Academy of Management Review, 7(2), 235-241.

[10] Aupperle, K.E., Carroll, A.B. and Hatfield, J.D. (1985). An empirical examination of the relationship between corporate social responsibility and profitability. Academy of Management Journal, 28(2), 446-463.

[11] Bae, K.-H., Jun-Koo Kang, J.-K. and Wang, J. (2011). Employee treatment and firm leverage: A test of the stakeholder theory of capital structure. Journal of Financial Economics, 100(1), 130-153.

[12] Balabanis, G., Phillips, h.c. and Lyall, J. (1998). Corporate social responsibility and economic performance in the top British companies: are they linked? European Business Review, 98(1), 25-44.

[13] Ball, R. (1978). Anomalies in relationships between securities' yields and yield-surrogates. Journal of Financial Economics, 6(2), 103-126.

[14] Bansal, P. (2005). Evolving sustainably: a longitudinal study of corporate sustainable development. Strategic Management Journal, 26(3), 197-218.

[15] Banz, R.W. (1981). The relationship between return and market value of common stocks. Journal of Financial Economics, 9(1), 3-18.

[16] Barnett, M.L. (2007). Stakeholder influence capacity and the variability of financial returns to corporate social responsibility. Academy of Management Review, 32(3), 794-816.

[17] Barnett, M.L. and Salomon, R.M. (2006). Beyond dichotomy: The curvilinear relationship between social responsibility and financial performance. Strategic Management Journal, 27(11), 1101-1122.

[18] Barney, J. (1991). Firm resources and sustained competitive advantage. Journal of Management, 17(1), 99-120.

[19] Baron, D.P. (2001). Private politics, corporate social responsibility, and integrated strategy. Journal of Economics \& Management Strategy, 10(1), 7-45.

[20] Belkaoui, A. and Kahl, a. (1978). Corporate Financial Disclosure in Canada, Research Monograph No. 1 of Canadian Certified General Accountants' Association.

[21] Berman, S.L., Wicks, A.C., Kotha, S. and Jones, T.M. (1999). Does stakeholder orientation matter? The relationship between stakeholder management models and firm financial performance. Academy of Management Journal, 42(5), 488-506.

[22] Bird, R., Hall, A.D., Momentè, F. and Reggiani, F. (2007). What corporate social responsibility activities are valued by the market? Journal of Business Ethics, 76(2), 189-206.

[23] Black, B.S. and Khanna, V.S. (2007). Can corporate governance reforms increase firm market values? Event study evidence from India. Journal of Empirical Legal Studies, 4(4), 749-796.

[24] Blazovich, J. and Smith, L.M. (2011). Ethical Corporate Citizenship: Does it Pay? Research on Professional Responsibility and Ethics in Accounting, 15, 127-163. 
[25] Bonin, J.P., Hasan, i. and Wachtel, P. (2005). Privatization matters: Bank efficiency in transition countries. Journal of Banking \& Finance, 29(8), 2155-2178.

[26] Bouchard, T.J. (1976). Unobtrusive measures an inventory of uses. Sociological Methods \& Research, 4(3), 267-300.

[27] Bowen, H.R. and Johnson, F.E. (1953). Social responsibility of the businessman, Harper, New York.

[28] Brown, K. (2001). Corporate social responsibility: Perceptions of Indian business. Maratha Mandir's [26] Babasaheb Gawde Institute of Management Studies. Retrieved on February 10: 2011.

[29] Campbell, J.L. (2007). Why would corporations behave in socially responsible ways? An institutional theory of corporate social responsibility. Academy of Management Review, 32(3), 946-967.

[30] Carroll, A.B. (1979). A three-dimensional conceptual model of corporate performance. Academy of management Review, 4(4), 497-505.

[31] Chapple, W. and Moon, J. (2005). Corporate social responsibility (CSR) in Asia a seven-country study of CSR web site reporting. Business \& Society, 44(4), 415-441.

[32] Chatterji, A.K. and Levine, D.I. (2008). Imitate or differentiate? Evaluating the validity of corporate social responsibility ratings. Center for Responsible Business.

[33] Chatterji, A.K., Levine, D.I. and Toffel, M.W. (2009). How well do social ratings actually measure corporate social responsibility? Journal of Economics \& Management Strategy, 18(1), 125-169.

[34] Cheung, Y.L., Tan, W.Q., Ahn, H.J. and Zhang, Z. (2010). Does corporate social responsibility matter in Asian emerging markets? Journal of Business Ethics, 92(3), 401-413.

[35] Chih, H.-L., Chih, H-H. and Chen, T-Y. (2010). On the determinants of corporate social responsibility: International evidence on the financial industry. Journal of Business Ethics, 93(1), 115-135.

[36] Choi, J.-S., Kwak, Y-M. and Choe, C. (2010). Corporate social responsibility and corporate financial performance: Evidence from Korea. Australian Journal of Management, 35(3), 291-311.

[37] Cochran, P.L. and Wood, R.A. (1984). Corporate social responsibility and financial performance. Academy of Management Journal, 27(1), 42-56.

[38] Cox, P., Brammer. S. and Millington, A. (2004). An empirical examination of institutional investor preferences for corporate social performance. Journal of Business Ethics, 52(1), 27-43.

[39] Delmas, M. and Toffel, M.W. (2004). Stakeholders and environmental management practices: an institutional framework. Business strategy and the Environment, 13(4), 209-222.

[40] Dooley, R.S. and Lerner, L.D. (1994). Pollution, profits, and stakeholders: The constraining effect of economic performance on CEO concern with stakeholder expectations. Journal of Business Ethics, 13(9), 701-711.
[41] Dowell, G., Hart, S. and Yeung, B. (2000). Do corporate global environmental standards create or destroy market value? Management Science, 46(8), 1059-1074.

[42] Du, S., et al. (2010). Maximizing business returns to corporate social responsibility (CSR), The role of CSR communication. International Journal of Management Reviews, 12(1), 8-19.

[43] El-Bannany, M. (2007). A study of determinants of social disclosure level in UK banks. Corporate Ownership \& Control, 5/1, 120-130.

[44] Engardio, P., et al. (2007). Beyond the green corporation: Imagine a world in which eco-friendly and socially responsible practices actually help a company's bottom line. It's closer than you think. Business Week, 4019, pp 50.

[45] Epstein, E.M. (1987). The corporate social policy process: Beyond business ethics, corporate social responsibility, and corporate social responsiveness. California Management Review, 29(3), 99-114.

[46] Epstein, M.J. and Roy, M.-J. (2001). Sustainability in action: Identifying and measuring the key performance drivers. Long range planning, 34(5), 585-604.

[47] Fauzi, H., et al. (2007). The link between corporate social performance and financial performance: evidence from Indonesian companies. Issues in Social and Environmental Accounting, 1(1), 149-159.

[48] Florinita, D. (2011). Financial Performance and Social Responsibility: Romanian Scenario. Ovidius University Annals, Economic Sciences Series, 11(1), 675-677.

[49] Fombrun, C. and Shanley, M. (1990). What's in a name? Reputation building and corporate strategy. Academy of Management Journal, 33(2), 233-258.

[50] Gallardo-Vázquez, D. and Sanchez-Hernandez, M.I. (2014) Measuring corporate social responsibility for competitive success at a regional level. Journal of Cleaner Production, $72,14-22$

[51] García, F. and Armas, Y. (2007). Relation between social-environmental responsibility and performance in hotels firms. International Journal of Hospitality Management, 26(4), 824-839.

[52] Gil, M.A., et al. (2001). An analysis of environmental management, organizational context and performance of Spanish hotels. Omega, 29(6), 457-471.

[53] Gildea, R.L. (1994). Consumer survey confirms corporate social action affects buy. Public Relations Quarterly, 39(4), 20-21.

[54] Goddard, J., et al. (2004). The profitability of European banks: a cross - sectional and dynamic panel analysis. The Manchester School, 72(3), 363-381.

[55] Graves, S.B. and Waddock, S.A. (1994). Institutional owners and corporate social performance. Academy of Management Journal, 37(4), 1034-1046.

[56] Griffin, J.J. and Mahon, J.F. (1997). The corporate social performance and corporate financial performance debate twenty-five years of incomparable research. Business \& Society, 36(1), 5-31. 
[57] Guernsey, L. (1999). Corporate Largesse: Philanthropy or Self-Interest? The Chronicle of Higher Education, 44(33).

[58] Hassan, A. and Abdul Latiff, h.s.b.a (2009). Corporate social responsibility of Islamic financial institutions and businesses: Optimizing charity value. Humanomics, 25(3), 177-188.

[59] Mulyadi, M. and Anwar, Y. (2012). Impact of Corporate Social Responsibility toward Firm Value and Profitability. The Business Review, Cambridge, 2(9), 316-322.

[60] Mulyadi, M.S. and Anwar, Y. (2011). Investor's perception on corporate responsibility of Indonesian listed companies. African Journal of Business Management, 5(9), 3630-3634.

[61] Naqvi, S.N.H. (1981). Ethics and economics: An Islamic synthesis, Islamic Foundation London.

[62] Naser, K., et al. (2002). Empirical evidence on the depth of corporate information disclosure in developing countries: The case of Jordan. International Journal of Commerce and Management, 12(3/4), 122-155.

[63] Nazir, M.S. and Afza, T. (2009). A panel data analysis of working capital management policies. Business Review, 4(1), 143-158.

[64] Nelling, E. and Webb, E. (2009). Corporate social responsibility and financial performance: the virtuous circle revisited. Review of Quantitative Finance and Accounting, 32(2), 197-209.

[65] Newgren, K.E., et al. (1985). Environmental assessment and corporate performance: A longitudinal analysis using a market-determined performance measure. Research in Corporate Social Performance and Policy, 7, 153-164.

[66] Pava, M.L. and Krausz, J. (1996). The association between corporate social-responsibility and financial performance: The paradox of social cost. Journal of Business Ethics, 15(3), 321-357.

[67] Porter, M.E. and Kramer, M.R. (2006). The link between competitive advantage and corporate social responsibility. Harvard Business Review, 84(12), 78-92.

[68] Posnikoff, J.F. (1997). Disinvestment from South Africa: They did well by doing good. Contemporary Economic Policy, 15(1), 76-86.

[69] Preston, L.E. and O'bannon, D.P. (1997). The corporate social-financial performance relationship. Business and Society, 36(4), 419-429.

[70] Roberts, G.E. (1992). Linkages between performance appraisal system effectiveness and rater and ratee acceptance. Review of Public Personnel Administration, 12(3), 19-41.

[71] Roberts, R.W. (1992). Determinants of corporate social responsibility disclosure: an application of stakeholder theory. Accounting, Organizations and Society, 17(6), 595-612.

[72] Schuler, D.A. and Cording, M. (2006). A corporate social performance-corporate financial performance behavioral model for consumers. Academy of Management Review, $31(3), 540-558$

[73] Schwaiger, M. (2004). Components and parameters of corporate reputation-an empirical study. Schmalenbach Business Review, 56, 46-71.

[74] Simpson, W.G. and Kohers, T. (2002). The link between corporate social and financial performance: evidence from the banking industry. Journal of Business Ethics, 35(2), 97-109.

[75] Singal, M. (2014). Corporate social responsibility in the hospitality and tourism industry: Do family control and financial condition matter? International Journal of Hospitality Management, 36, 81-89.

[76] Trotman, K.T. and Bradley, G.W. (1981). Associations between social responsibility disclosure and characteristics of companies. Accounting, Organizations and Society, 6(4), $355-362$.

[77] Tsoutsoura, M. (2004). Corporate social responsibility and financial performance. Center for Responsible Business, University of California, Berkeley.

[78] Turker, D. (2009). Measuring corporate social responsibility: A scale development study. Journal of Business Ethics, 85(4), 411-427.

[79] Ullmann, A.A. (1985). Data in search of a theory: A critical examination of the relationships among social performance, social disclosure, and economic performance of US firms. Academy of management Review, 10(3), 540-557.

[80] Uwuigbe, O., et al. (2011). Cash management and corporate profitability: a study of selected listed manufacturing firms in Nigeria. Acta Universitatis Danubius. Economica, 8(1).

[81] Veronica Siregar, S. and Bachtiar, Y. (2010). Corporate social reporting: empirical evidence from Indonesia Stock Exchange. International Journal of Islamic and Middle Eastern Finance and Management, 3(3), 241-252.

[82] Wood, D.J. (1991). Corporate social performance revisited. Academy of Management Review, 16(4), 691-718.

[83] Wright, P. and Ferris, S.P. (1997). Agency conflict and corporate strategy: The effect of divestment on corporate value. Strategic Management Journal, 18(1), 77-83.

[84] Wu, M.-W. and Shen, C.-H. (2013). Corporate social responsibility in the banking industry: Motives and financial performance. Journal of Banking \& Finance, 37(9), $3529-3547$.

[85] Zahra, S.A. and Stanton, W.W. (1988). The implications of board of directors' composition for corporate strategy and performance. International Journal of Management, 5(2), 229-236.

[86] Zairi, M. and Peters, J. (2002). The impact of social responsibility on business performance. Managerial Auditing Journal, 17(4), 174-178. 